\title{
SPRAY-FORMED ALLOY 718
}

\author{
M.G. Benz, R.J. Zabala, P.L. Dupree, B.A. Knudsen, \\ W.T. Carter, and T.F. Sawyer \\ GE Corporate Research and Development Center \\ Schenectady, NY 12301
}

\begin{abstract}
Spray-formed Alloy 718 has been studied with respect to microstructure, compositional uniformity, processability, and mechanical performance. The results suggest that this approach, plus an upset and draw sequence of hot working, can be used to form billets suitable for forging and ring-rolling. Mechanical properties achieved with laboratory-scale billets are similar to those achieved for conventionally cast and wrought Alloy 718.
\end{abstract}

\section{Spray Forming}

Spray forming is potentially an alternative process to "triple melting" vacuum induction melting (VIM), plus electro-slag refining (ESR), plus vacuum arc remelting (VAR) for the melting and solidification of Alloy 718. In this case, a liquid metal stream is extracted from a melting operation and passed through an argon or nitrogen gas jet atomizer. The resulting alloy droplets, 100 to $300 \mu \mathrm{m}$ in diameter, are sprayed directly onto a collector, where they flatten into a liquid layer, solidify and build up a preform. The preform is then converted to a billet by an upset and draw sequence. Figure 1 shows schematically the major elements of the sprayforming process.

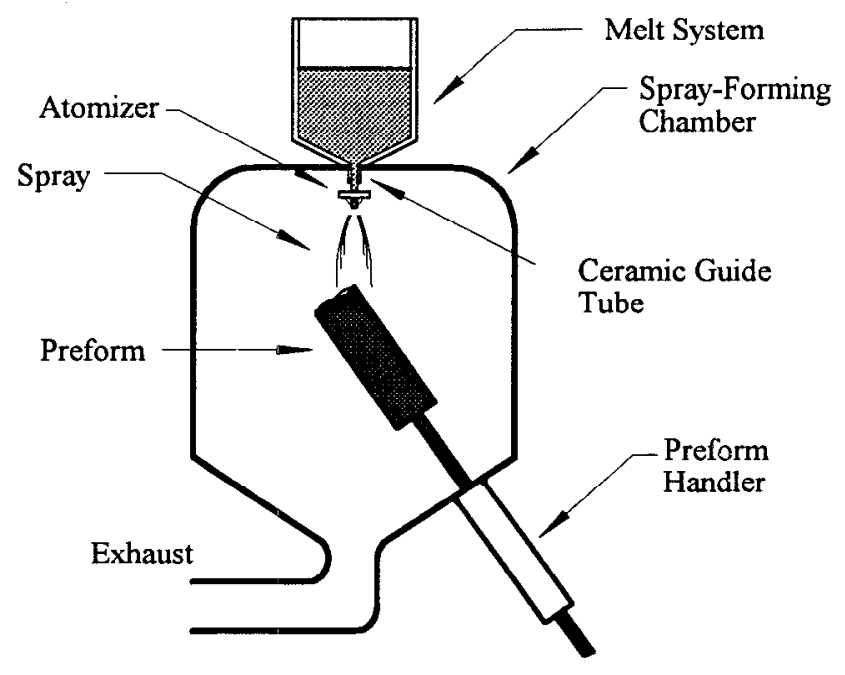

Figure 1 - Spray-forming system 


\section{Background}

Spray forming, as described above, was first explored for aluminum-base and iron-base alloys (1-3). Over the past decade, this technology has been extended (4) and has currently reached the level of commercial production for stainless steel tubes $(5,6)$, rolling mill rolls (7), and aluminum compressor rotors (18). Spray forming was first explored for superalloys with the alloy Nimonic 80A (9). "Centrifugal spray forming," making use of rotating-disk atomization, was used in this case. Gas-atomized spray forming (as shown in Figure 1) was explored soon thereafter, using the alloy Rene'80 (10). This later work concluded that superalloys could be atomized and directly deposited while still maintaining low oxygen content, low porosity, and acceptable strength and ductility. Gas-atomized spray-forming technology has since evolved to reach the level of commercial offering of spray-formed preforms of Alloy 718, Rene' 41 and Waspaloy for ring-rolling and flow-forming (11).

Much of the development work on spray forming of superalloys has been conducted with Alloy 718. In the following discussion, we summarize the observations reported in the literature. For the first experiments, disks from Alloy $718,150 \mathrm{~mm}$ in diameter by $120 \mathrm{~mm}$ high, and tubes $100 \mathrm{~mm}$ in diameter by $30 \mathrm{~mm}$ thick were formed with a research-sized spray-forming unit, using nitrogen and argon as two variations of the atomizing gas (12). Grain size, oxygen content, nitrogen content, porosity, tensile strength at room temperature, and tensile strength and stress rupture life at $650{ }^{\circ} \mathrm{C}$ were measured. The average grain size as-deposited was 20 to 30 $\mu \mathrm{m}$. The observed oxygen content, nitrogen content, and porosity are summarized in Table I.

Table I. Metallurgical Parameters Observed for Alloy 718 (12)

\begin{tabular}{l|l|l}
\hline Parameter & $\begin{array}{l}\text { Nitrogen- } \\
\text { atomized } \\
\text { Preforms }\end{array}$ & $\begin{array}{c}\text { Argon- } \\
\text { atomized } \\
\text { Preforms }\end{array}$ \\
\hline Oxygen Content & $<35 \mathrm{ppm}$ & $<35 \mathrm{ppm}$ \\
Nitrogen Content & $<330 \mathrm{ppm}$ & $<90 \mathrm{ppm}$ \\
Porosity & $<0.3 \%$ & $<3.3 \%$ \\
\hline
\end{tabular}

The best mechanical properties were achieved when using nitrogen as the atomizing gas and when following the spray-forming operation by forging step (55\% reduction). Table II summarizes the results for material processed in this manner.

Table II. Mechanical Properties Observed for Alloy 718 Spray Formed + Forged 55\% (12)

\begin{tabular}{l|l|l}
\hline Property & \multicolumn{1}{|c|}{$\begin{array}{c}\text { Room } \\
\text { Temperature }\end{array}$} & $\mathbf{6 5 0}^{\circ} \mathbf{C}$ \\
\hline Tensile & 190 to 198 & 152 to 159 \\
$0.2 \%$ YS (ksi) & 211 to 217 & 174 to 176 \\
UTS (ksi) & 11 to 13 & 14 to 16 \\
Elongation (\%) & 20 to 22 & 25 to 28 \\
RA (\%) & & \\
Stress Rupture & & 243 to 248 \\
Life at $105 \mathrm{ksi}(\mathrm{hr})$ & 8 to 11 \\
Elongation at $105 \mathrm{ksi}(\%)$ & & 27 to 68 \\
Life at $120 \mathrm{ksi}(\mathrm{hr})$ & 5 to 7 \\
Elongation at $120 \mathrm{ksi}(\%)$ & & \\
\hline
\end{tabular}


These properties compared quite favorably to commercially available cast and forged Alloy 718 $(13,14)$. The higher nitrogen content of the nitrogen-atomized alloy did not create a problem, because the added nitrogen was present as very fine micron-sized precipitates of nitrides and carbonitrides. When argon was used as the atomizing gas, however, an increased amount of porosity was observed, and this porosity resulted in slightly lower (30\%) tensile ductility and in a lower and significantly scattered (30X) stress rupture life. The beneficial effects of nitrogen atomization and forging after spray forming have also been confirmed for six other superalloy systems (Waspaloy, Rene'95, AF-115, AF2-1DA, MERL76, and Astroloy) (15-17).

A quantitative study of microsegregation was performed using the electron microprobe (18). Segregation ratios were observed for niobium, aluminum, molybdenum, titanium, and chromium. Comparison to as-cast VIM/ESR Alloy 718 and VIM/VAR plus forged Alloy 718 showed the degree of microsegregation for the spray-formed samples to be comparable to the VIM/VAR plus forged samples (less microsegregation than for the as-cast VIM/ESR samples). Macrosegregation was also reviewed and considered to be near-zero for the spray-formed samples. Oxygen and nitrogen contents were measured and are listed in Table III.

Table III. Oxygen and Nitrogen Contents Observed for Alloy 718 (18)

\begin{tabular}{l|l|l}
\hline Parameter & $\begin{array}{l}\text { Oxygen } \\
\text { Content } \\
\text { (ppm) }\end{array}$ & $\begin{array}{l}\text { Nitrogen } \\
\text { Content } \\
\text { (ppm) }\end{array}$ \\
\hline As-cast VIM/ESR & 10 & 60 \\
VIM/VAR plus Forged & 26 & 99 \\
Argon-Atomized Preform & 29 & 72 \\
$\begin{array}{l}\text { Nitrogen-Atomized } \\
\text { Preforms }\end{array}$ & 10 to 20 & 211 to 288 \\
\hline
\end{tabular}

The higher nitrogen content for the nitrogen-atomized preforms was not observed to be detrimental to mechanical properties. Tensile properties measured at room temperature were similar to those previously reported (See Table II above). Fracture toughness for the sprayformed material was found to be comparable to VIM/VAR plus forged Alloy 718. X-ray mapping suggested that the added nitrogen was present as grain boundary precipitates of titanium-rich nitrides or carbonitrides. The solubility limit for nitrogen in liquid Alloy 718 at the solidification temperature is estimated to be in the range of 15 to $20 \mathrm{ppm}$ (19). Nitrogen contents above this level should contain precipitates of Nb-rich and Ti-rich nitrides or carbonitrides.

Transmission clectron microscopy has been used to disclose the nature of the precipitates in nitrogen-atomized Rene'95 (20). These micron sized precipitates have been shown to be agglomerates of Ti-rich and $\mathrm{Nb}$-rich nitrides and carbonitrides, as shown in Figure 2. The precipitates appear to occur by formation of clusters of submicron melt-formed crystals. The individual crystals in each cluster are complex $(\mathrm{Ti}, \mathrm{Nb})(\mathrm{C}, \mathrm{N})$ carbonitrides, showing in some cases substantial variations in the $\mathrm{Ti} / \mathrm{Nb}$ ratio. The individual crystals do not appear to have a crystallographic relationship with each other or with the superalloy matrix and seem to be sintered together at necks or bridges. These factors indicate that the $(\mathrm{Ti}, \mathrm{Nb})(\mathrm{C}, \mathrm{N})$ type crystals precipitated while the matrix was in the liquid state and that they clustered together by a liquid state agglomeration process. The precipitates in Alloy 718 are thought to form by a similar process. 


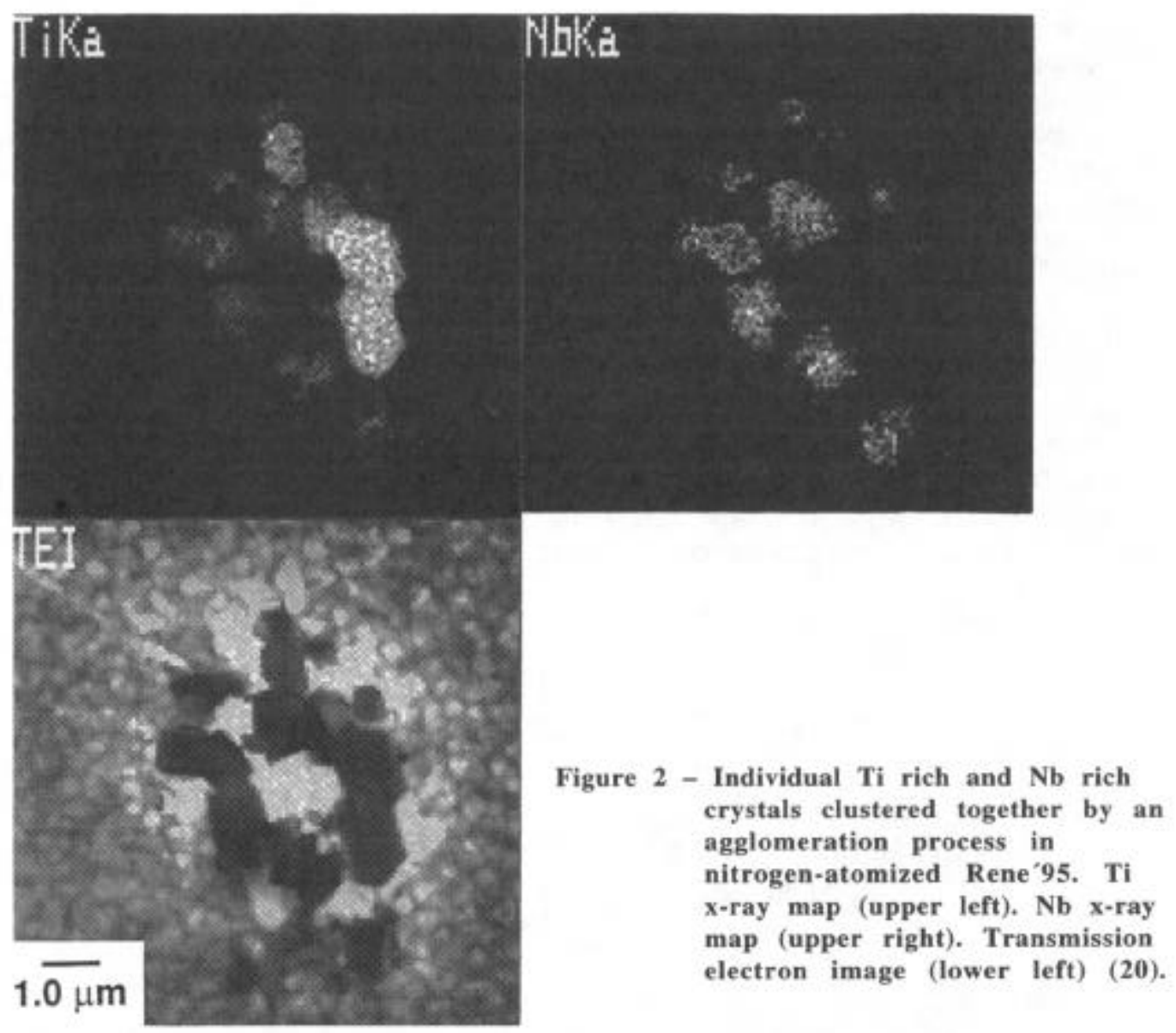

Later experience with argon atomization was more successful for Alloy 718 than the earlier experience. The as-deposited porosity continues to run about 2 to $3 \%$, but this porosity is reduced to less than $0.1 \%$ by high levels of deformation (press forging with a 55 to $75 \%$ upset) (21). Heat treatment at a temperature of $1250^{\circ} \mathrm{C}\left(150^{\circ} \mathrm{C}\right.$ above the press forging temperature and $268^{\circ} \mathrm{C}$ above the solution temperature) to detect thermally induced porosity (TIP) caused $0.4 \%$ porosity to return. This level of porosity is acceptable for many applications. Ring-rolling and flow-forming have also been shown to give sufficient deformation to produce similar results (11).

\section{Laboratory Experiments}

Equipment. General Electric is a licensee of Osprey Metals, Ltd. In early 1984, a sprayforming research facility was established at the General Electric Corporate Research and Development Center in Schenectady, NY. This spray-forming facility consists of a $50 \mathrm{~kg}$ vacuum/inert atmosphere induction heated melting chamber mounted on top of a "research size" spray-forming unit. The melting chamber contains (1) a magnesia melting crucible capable of accepting a $50 \mathrm{~kg}$ charge, (2) a ceramic liquid metal flow control nozzle cemented into the bottom of the melting crucible, (3) a $225-\mathrm{kW}, 3000-\mathrm{Hz}$ induction coil positioned such that the charge melts from the top, (4) valves to allow the chamber to be evacuated and back filled with argon prior to melting, (5) thermocouples to measure the melt temperature, and (6) an argon pressure compensation system used to maintain a constant gas plus liquid metal head 
pressure above the flow control nozzle, as the liquid metal head is lowered during a run. The spray-forming unit was originally fabricated by Osprey Metals, Ltd. It is currently equipped with (1) a scanning atomizer of the standard Osprey Metals, Ltd. design, (2) a servo-electric system to control the motion of the scanning atomizer, (3) an atomizing gas control system, allowing the use of either argon or nitrogen as the atomizing gas, (4) a horizontal collector capable of disk or tubular preform operation, (5) an angled collector capable of billet preform operation, (6) a servo-hydraulic system to control the motion of the collectors, (7) an exhaust gas system, (8) instrumentation to measure temperatures, and (9) video systems to observe atomization and deposition regions of the process.

Microstructure. The microstructure for "as-deposited" Alloy 718 is shown in Figure 3.

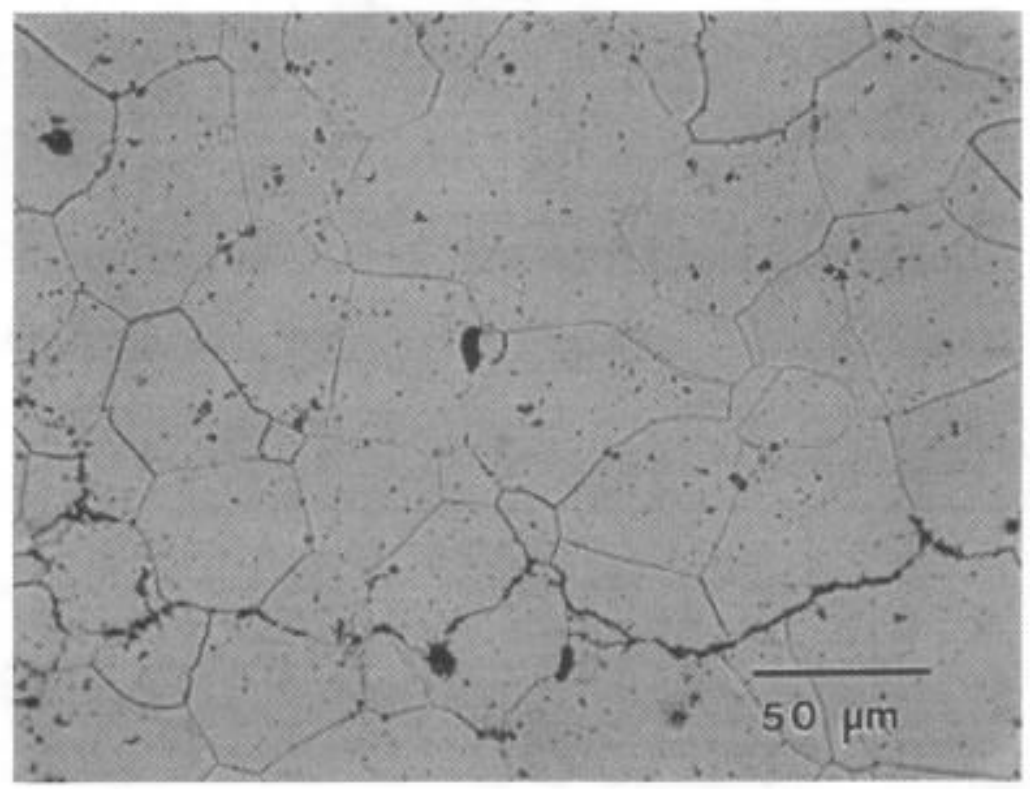

Figure 3 - Microstructure - spray-formed alloy 718

The morphology of this microstructure is established during the solidification phase of spray forming. The process parameters are set so as to maintain a thin, partially liquid layer on the surface of the preform in the deposition zone. Solidification occurs just below this partially liquid layer. The temperature gradient in the liquid at the solid-to-liquid interface, the rate at which the solid-to-liquid interface moves, the diffusion coefficient for the solute in the liquid, and the freezing range of the alloy all interact to establish the morphology of the solidifying grains. In this case, equiaxed cells are formed. These grains grow slightly, to the size seen in Figure 3 , by a grain growth process as the solidified grains cool slowly during continued growth of the preform.

After forging and heat treatment, the microstructure for Alloy 718 is as shown in Figure 4. This structure is comparable to that produced by triple melt, plus upset and draw, plus forging, plus heat treatment.

Forging and Ring-rolling. The uniform grain size in the $20-$ to $30-\mu \mathrm{m}$ range and the low levels of micro- and macro-segregation make the spray-formed Alloy 718 preforms excellent for subsequent forging and ring-rolling. Billet forging has been conducted with good success for both nitrogen-atomized and argon-atomized material, the argon-atomized preforms having higher level of porosity. However, ring-rolling has been observed to place a more stringent demand on the absence of porosity (22). 


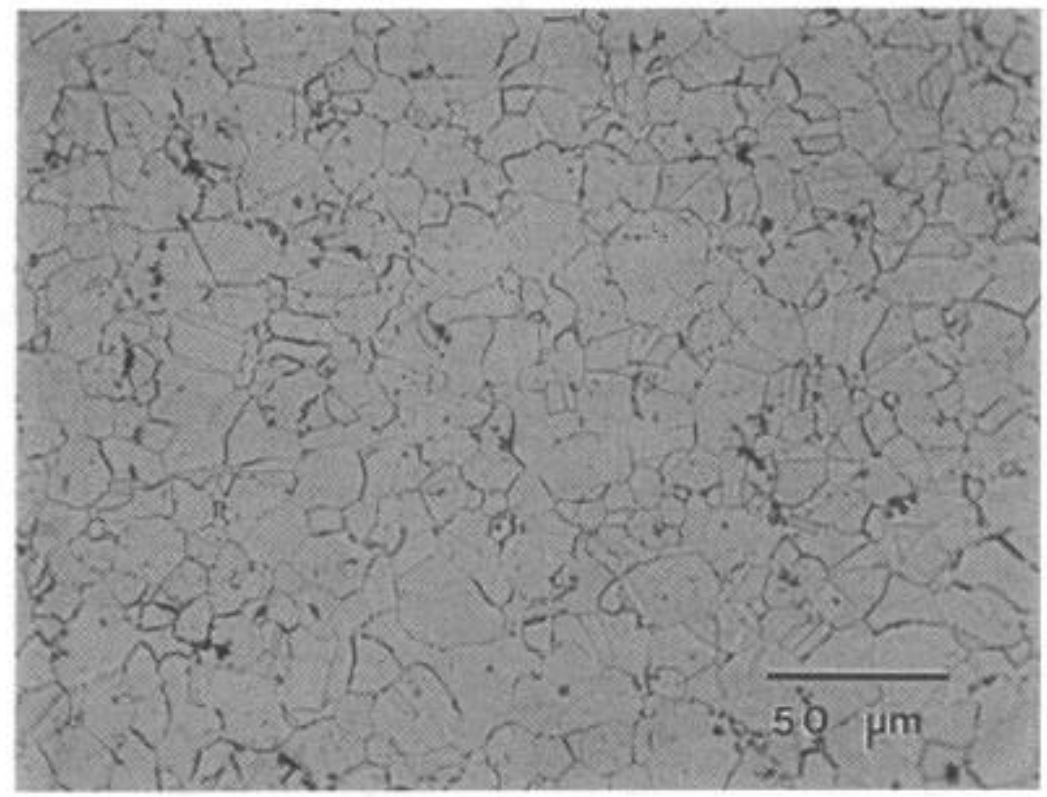

Figure 4 - Microstructure - spray formed + HIP + forged alloy 718

First efforts at ring-rolling made use of as-deposited tubular preforms. Tubular preforms, in general, show a slightly higher level of porosity than disk- or billet-shaped preforms, and in this particular case, the porosity level at the midthickness of the tube was even slightly higher than the average. On ring-rolling, a "chevron-type" crack pattern formed at the midthickness of the completed ring. This pattern looked very similar to the pattern reported in the literature for midthickness defects in sheet rolling and sheet drawing (23). The explanation of this phenomenon for sheet drawing is the presence of hydrostatic tensile stresses at the midthickness of the sheet, causing voids that are present to grow. In ring-rolling, midthickness hydrostatic tensile stresses are also present and can be expected to expand any pores that are present.

To test the theory that the absence of pores before ring-rolling would lead to the absence of midthickness cracks after ring-rolling, a preform was made from a nitrogen-atomized sprayformed disk that was forged, pierced, and ring-rolled as outlined in Table IV.

Table IV. Forging and Ring-rolling Procedure (22)

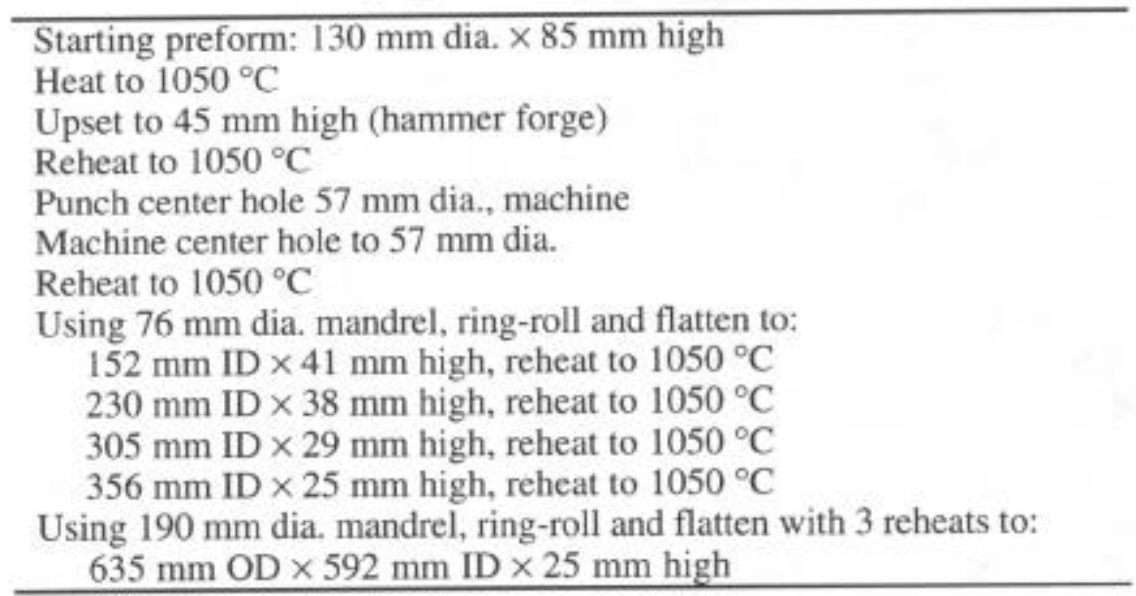


With this sequence, no pores were observed before ring-rolling, and no midthickness cracks were observed after ring-rolling. To extend this pore-free requirement to argon-atomized tubular preforms containing porosity, a hot-isostatic-pressing (HIP) densification step was placed between the spray-forming step and the ring-rolling step. This eliminated the presence of pores before ring-rolling and no midthickness cracks were observed after ring-rolling. This technique has been used successfully in the laboratory with Alloy 718, IN907, L605 and Rene'220 (24). This approach has been applied to aircraft engine type rings with the Alloy 718 , Rene'41, and Waspaloy $(11,25)$.

\section{Future Directions}

Spray forming looks promising as a process to form preforms for forging and ring-rolling. This technology must confront three major challenges if it is to be used more extensively for the production of superalloys: lower porosity, freedom from ceramic inclusions, and lower cost.

Lower porosity. Porosity has been shown to reduce stress rupture life in Alloy $718(13,14)$, and to reduce low-cycle fatigue (LCF) life in Rene' $95(17,20)$. The preferred current approach is to switch from argon, as the atomizing gas, to nitrogen as the atomizing gas, trading off higher nitrogen contents and micron-sized carbonitride precipitates for the $100-\mu \mathrm{m}$-sized pores that occur with argon atomization. These micron-sized titanium and niobium carbonitride agglomerates are sufficiently small that they do not appear to influence LCF life (20). They are melt-formed and are not likely to grow substantially during solid-state processing or during operation of the component. However, nitrogen levels in the starting melt stock should continue to be carefully monitored to make sure that carbonitride agglomeration to larger than micronsized precipitates does not occur during the initial melting stage. Alternatively, the second approach is to use argon as the atomizing gas and to follow the spray forming with sufficiently heavy deformation to reduce the pore size $(13,14)$. Argon atomization is attractive because of the lower levels of nitrogen, but this approach seems much more difficult to monitor. As a future direction, therefore, an open question for process development should remain, "How can the spray-forming process be changed to reduce porosity when argon is used as the atomizing gas?" Novel techniques, such as changes in the atomizer, changes in the gas-to-metal surface tension relationships, or low-pressure spray-forming chambers have been proposed.

Freedom from ceramic inclusions and lower cost. Ceramic inclusions have been shown to reduce LCF life in Rene'95 $(17,20)$. Melting with VIM in a "cleaner" manner has been demonstrated as making improvements (26). Cost is still a factor. As a future direction, therefore, an open question for process development should remain, "Can a method be devised to both improve the cleanliness of the melt and also to lower the cost?" In response to this question, a novel melting approach has been proposed that extracts a liquid metal stream from the bottom of an ESR furnace via a cold-wall-induction guide tube and then uses this stream directly for spray forming (27). Figure 5 is a schematic of the major elements of this approach. 


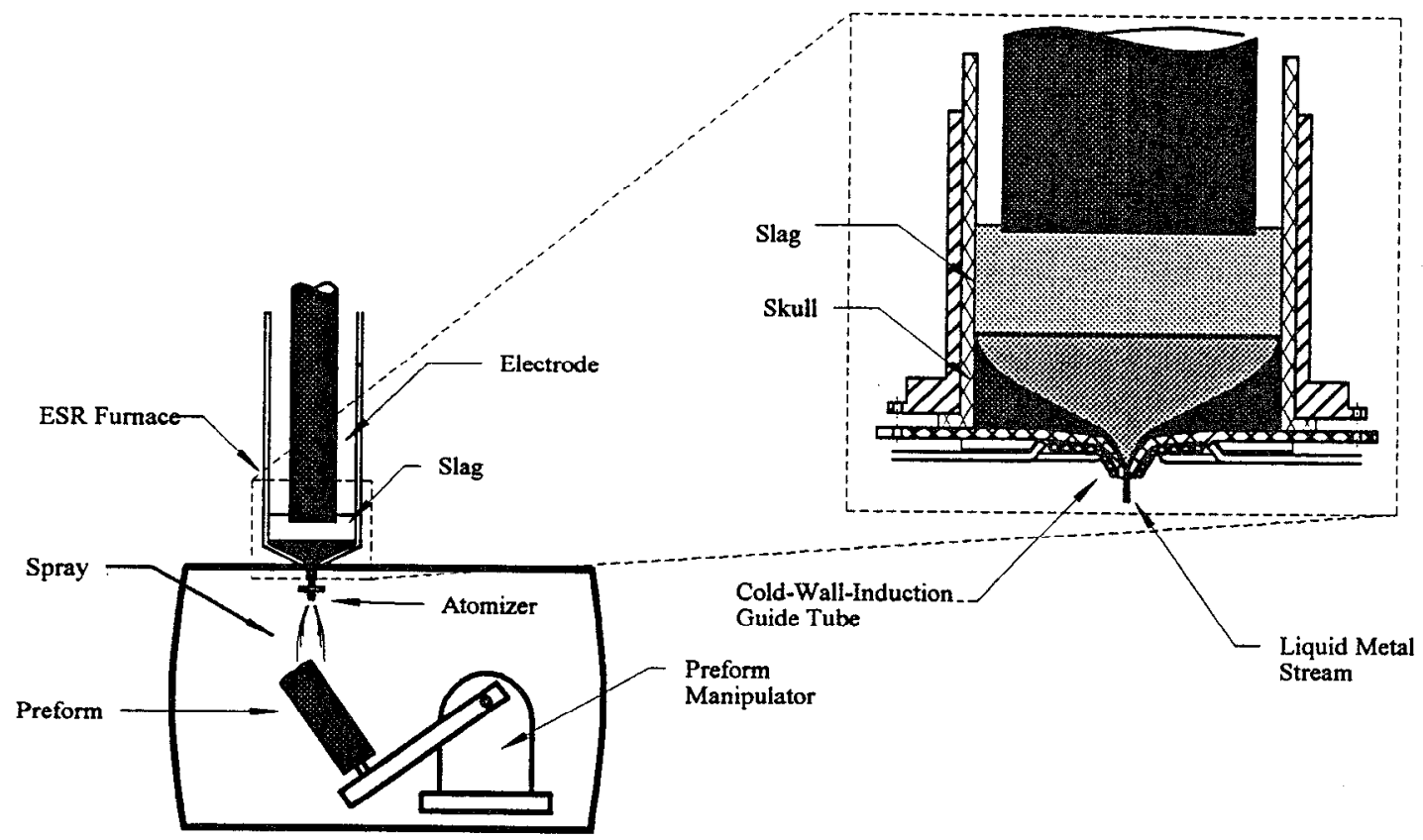

Figure 5 - ESR melting combined with spray forming (27)

\section{Summary and Conclusions}

Spray forming is potentially an alternative process to "triple melting" for preparation of Alloy 718 preforms to be converted into billets by an upset and draw sequence. Spray forming is being used today for introductory scalc commercial production of stainless stcel tubes, stecl rolling mill rolls, aluminum compressor rotors, and superalloy rings.

For superalloys, the level of porosity achieved is 1 to $3 \%$, when argon is used as the atomizing gas, and less than $1 \%$, when nitrogen is used as the atomizing gas. Nitrogen levels in the 200to $350-\mathrm{ppm}$ range are observed when nitrogen is used as the atomizing gas. This nitrogen is present as small micron-sized melt-formed precipitates of $(\mathrm{Ti}, \mathrm{Nb})(\mathrm{C}, \mathrm{N})$ carbonitrides. These precipitates have not been shown to adversely affect tensile, toughness, stress rupture, and LCF properties.

Spray forming produces a preform that has a 20 - to $30-\mu \mathrm{m}$-equiaxed grain size. The uniform grain size and the low levels of micro- and macro-segregation observed make the spray-formed superalloy preforms excellent for subsequent forging and ring-rolling. Tensile, toughness, stress rupture and LCF properties have been shown to be equal to those for superalloys produced by current production methods.

This technology faces three major challenges if it is to be used more extensively for the production superalloys: lower porosity, freedom from ceramic inclusions, and lower cost. Nitrogen atomization has been proposed to lower porosity. A novel melting technique, extracting a liquid metal stream from an ESR furnace, has been proposed to provide freedom from ceramic inclusions and to lower cost. 


\section{Acknowledgments}

The authors would like to acknowledge the forging by J.R. Hughes, analytical electron microscopy by E.L. Hall, many helpful discussions with M.F. Henry and E.S. Huron, and encouragement by T.B. Cox.

\section{References}

1. A.R.E. Singer: Met. Mater., 1970, Vol. 4, pp. 246-250, 257.

2. A.R.E. Singer and R.W. Evans: "Incremental Solidification and Forming," Metals Technology, 1983, Vol. 10, pp. 61-68.

3. R.G. Brooks, A.G. Leatham, J.S. Coombs, and C. Moore: Metall. Met. Form., April 1977, p. 157.

4. A.G. Leatham, A. Ogilvy, and L. Elias: "The Osprey Process Current Status and Future Possibilities," P/M in Aerospace, Defense and Demanding Technologies, San Diego, Feb. 7-10, 1993, to be published by MPIF.

5. A.L. Moran, M. Yaman, A. Wilson: "Large Scale Production of Spray Deposited Tubes in Alloy 625," Advances in Powder Metallurgy \& Particulate Materials -- 1992, San Francisco, June 21 - 26, 1992, Vol. I, pp. 337-348, 1992.

6. A.L. Moran and W.A. Palko: "Spray Forming Alloy 625 Marine Piping," Journal of Metals, 1988, Vol. 40, No. 12, pp. 12-15.

7. K. Kumagai, T. Itami and Y. Kawashima: "Latest Status of Developments and Applications of the Osprey Process," Proceedings of the Second International Conference on Spray Forming, Swansea, UK, September 13 - 15, Woodhead Publishing, Cambridge, UK, pp. 207-219, 1993.

8. H. Sano, N. Tokizane, Y. Ohkubo, and K. Sibue: "Spray Formed Aluminum Alloy Components for Automotive Applications," Proceedings of the Second International Conference on Spray Forming, Swansea, UK, September 13 - 15, Woodhead Publishing, Cambridge, UK, pp. 363-375, 1993.

9. A.R.E. Singer, D.J. Hodkin, P.W. Sutcliffe, and P.G. Mardon: "Centrifugal Spray Forming of Large Diameter Tubes," Metals Technology, 1983, Vol. 10, No. 3, pp. 105-110.

10. R.H. Bricknell: "The Structure and Properties of a Nickel-Based Superalloy Produced by Osprey Atomization Deposition,” Met. Trans., 1986, Vol. 17A, pp. 583-591.

11. P Delal and P.D. Prichard: "Thermomechanical Processing of Spraycast-X Superalloys," Proceedings of the Second International Conference on Spray Forming, Swansea, UK, September 13 - 15, Woodhead Publishing, Cambridge, UK, pp. 141-153, 1993.

12. H.C. Fiedler, T.F. Sawyer and R.W. Kopp: "Spray Forming - An Evaluation Using IN718," Proceedings of 1986 Vacuum Metallurgy Conference on Specialty Metals Melting and Processing, AIME, Warrendale, PA, pp. 157-165, 1987.

13. H.C. Fiedler, T.F. Sawyer R.W. Kopp, and A.G. Leatham: "The Spray Forming of Superalloys," Proceedings of PM Aerospace Materials '87, MPR Publishing, Shrewsbury, UK, pp. 15.1-15.13, 1988.

14. H.C. Fiedler, T.F. Sawyer R.W. Kopp, and A.G. Leatham: "The Spray Forming of Superalloys," Journal of Metals, 1987, Vol. 39, No. 8, pp. 28-33. 
15. H. Puschnik, H. Jager, F. Heinemann: "Spray Formed Waspaloy for Disc Forgings,"

Proceedings of PM Aerospace Materials '87, MPR Publishing, Shrewsbury, UK, pp. 14.114.7, 1988.

16. K-M Chang and H.C. Fiedler: "Spray-Formed High-Strength Superalloys," Superalloys 1988, Proceedings of the Sixth International Symposium, Edited by S. Reichman, et al., TMSAIME, Warrendale, PA, pp. 485-493, 1988.

17. H.C. Fiedler, T.F. Sawyer and R.W. Kopp: "Spray Formed Rene'95," GE Corporate Research and Development Center Report 87CRD034, March 1987.

18. R.L. Kennedy, R.M. Davis, and F.P. Vaccaro: "An Evaluation of Spray Formed Alloy 718," Superalloy 718 - Metallurgy and Applications, Edited by E.A. Loria, TMS-AIME, Warrendale, PA, pp. 97-108, 1989.

19. A. Mitchell: "Inclusions and the EB Refining of Superalloys," P/M in Aerospace, Defense and Demanding Technologies, San Diego, Feb. 7-10, 1993, to be published by MPIF.

20. M.G. Benz, T.F. Sawyer, W.T. Carter, R.J. Zabala and P.L. Dupree: "Nitrogen in Spray Formed Superalloys," Proceedings of the Second International Conference on Spray Forming, Swansea, UK, September 13 - 15, Woodhead Publishing, Cambridge, UK, pp. 171-181, 1993.

21. M.G. Benz, T.F. Sawyer, W.T. Carter, F.W. Clark and P.L. Dupree: "Properties of Superalloys Spray Formed at a Process Flow Rate of $20 \mathrm{~cm}^{3} / \mathrm{s}$," Proceedings of the First International Conference on Spray Forming, Swansea, UK, September 17-19, 1990.

22. H.C. Fiedler, T.F. Sawyer and R.W. Kopp: "Ring-rolling Spray Formed IN718 and CH.22," GE Corporate Research and Development Center Report 87CRD099, June 1987.

23. L.F. Coffin, Jr. and H.C. Rogers: "Influence of Pressure on the Structural Damage in Metal Forming Processes," Trans. ASM, 1967, Vol. 6, No. 4, pp. 672-686.

24. H.C. Fiedler, R.W. Kopp and T.F. Sawyer: "Ring-rolling Spray-Formed Alloys L605, IN907, CH22, and CH59A at Schlosser Forge," GE Corporate Research and Development Center Report 87CRD258, December 1987.

25. E.S. Huron: "Properties of Spray Formed Superalloy Rings," Proceedings of the Second International Conference on Spray Forming, Swansea, UK, September 13 - 15, Woodhead Publishing, Cambridge, UK, pp. 155-164, 1993.

26. P.D. Prichard and R.P. Delal: "Spraycast-X Superalloy for Aerospace Applications," Superalloys 1992, Proceedings of the Seventh International Symposium on Superalloys, Edited by S.D. Antolovich, et al., TMS-AIME, Warrendale, PA, pp. 205-214, 1992.

27. M.G. Benz and T.F. Sawyer: "Direct Processing of Electroslag Refined Metal," US Patent 5,160,532, Nov. 3, 1992. 